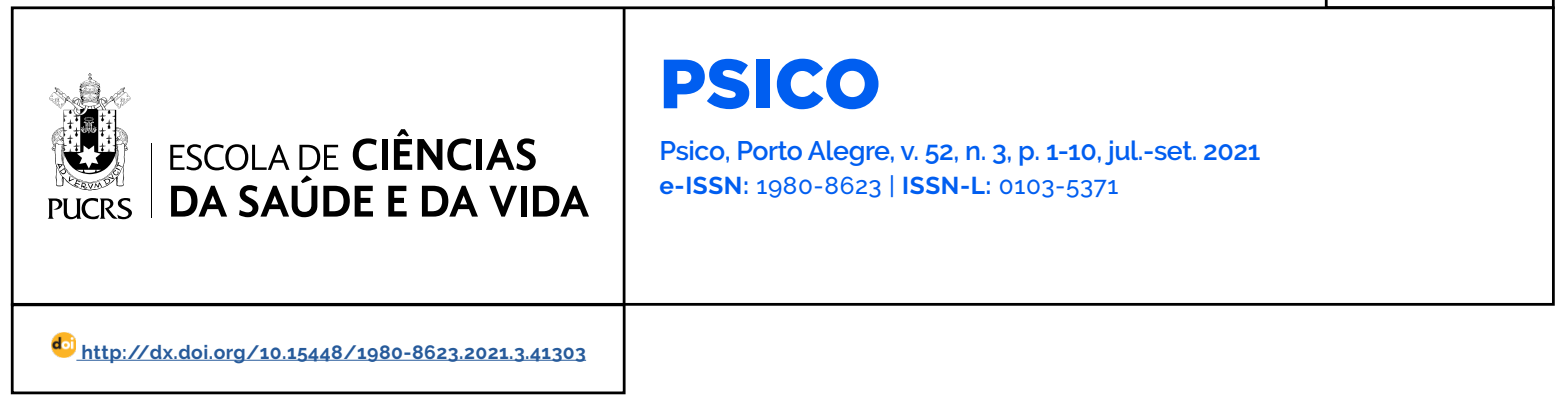

SEÇÃO: ARTIGO

\title{
More than one year surfing the waves of covid-19... and now the vaccination
}

\author{
Mais de um ano a surfar as ondas da covid-19... E agora a vacinação \\ Más de un año surfeando las olas de covid-19... Y ahora el vacunación
}

\section{Cátia Branquinho ${ }^{1}$}

orcid.org/0000-0002-2877-4505

catiasofiabranquinho@gmail.com

\section{Margarida Gaspar de \\ Matos $^{1}$}

orcid.org/0000-0003-2114-2350

mmatos@fmh.ulisboa.pt

Received on: 12 jul. 2021.

Approved on: 28 jul. 2021.

Published on: 27 oct. 2021

\section{(c) (i)}

Artigo está licenciado sob forma de uma licença Creative Commons Atribuição 4.0 Internacional.
Abstract: Adolescents and young adults (AYA) have the skills to contribute to the issues that affect them. This work present the opinions/experiences of Portuguese AYA, related to COVID-19, based on four multi-method studies with participants aged 16-24 years: ( $1^{\text {st }}$ lockdown) $617(M=19.1$ years, $S D=2.352)$; (Back to school) $304(M=18.4$ years, $S D=2.12)$; ( $2^{\text {nd }}$ lockdown) $592(M=19.01$ years, $S D=2.32$ ) and (Vaccination) $558(M=19.34$ years, $S D=2.266)$. In general, results shown that AYA have a negative perspective, especially girls and university students. Most are well informed about the general aspects and trust in vaccination benefits.

As conclusion, this study shows AYA competence to participate in the issues that affect them and their ability to propose strategies that may mitigate negative effects and promote a few positive ones.

Keywords: adolescent and young adults' participation, covid-19, pandemic, portugal, multimethod research

Resumo: Adolescentes e jovens adultos (AJA) têm as competências necessárias para contribuir para as questões que os afectam. Este trabalho apresenta as opiniões/experiências dos AJA portugueses relacionadas com a COVID-19, com base em quatro estudos multi-método com participantes dos 16-24 anos: ( $1^{\circ}$ confinamento) $617(M=19,1$ anos, $D P=2,352)$; (Regresso à escola) 304 ( $M=18,4$ anos, $D P=2,12)$; ( $2^{\circ}$ confinamento) $592(M=19,01$ anos, $D P=2,32)$ e (Vacinação) 558 $(M=19,34$ anos, $D P=2,266)$. No geral, os resultados mostram que os AJA têm uma perspectiva negativa, especialmente as raparigas e os estudantes universitários. Maioria está bem-informada sobre os aspectos gerais e confia nos benefícios da vacinação. Como conclusão, este estudo mostra a competência da AJA para participar nas questões que os afetam e a sua capacidade de propor estratégias que possam mitigar os efeitos negativos e promover alguns positivos.

Palavras-chave: participação de adolescentes e jovens adultos, covid-19, pandemia, portugal, investigação multimétodo

Resumen: Los adolescentes y jóvenes adultos (AJA) tienen las habilidades necesarias para contribuir a los asuntos que les afectan. Este estudio presenta las opiniones/experiencias de los AJA portugueses, relacionadas con el COVID-19, en base a cuatro estudios multimétodo con participantes de 16 y 24 años: ( $1^{\circ}$ confinamiento) 617 ( $M=19,1$ años, $D T=2,352)$; (Regreso a la escuela) 304 ( $M=18,4$ años, $D T=2,12)$; ( $2^{\circ}$ confinamiento) 592 ( $M=19,01$ años, $D T=2,32$ ) y (Vacunación) $558(M=19,34$ años, $D T=2,266)$. En general, los resultados muestran que los AJA tienen una perspectiva negativa, especialmente las chicas y los estudiantes universitarios. La mayoria está bien informada sobre los aspectos general y confia en los beneficios de la vacunación. En conclusión, este estudio muestra la competencia de los AJA para participar en los asuntos que les afectan y su capacidad para proponer estrategias que puedan mitigar los efectos negativos y promover algunos positivos.

Palabras clave: participación de adolescentes y jóvenes, covid-19, pandemia, portugal, investigación multimétodo 
Declared a pandemic on 11 March 2020, the disease COVID-19 is currently responsible for more than 845,000 cases in Portugal and more than 17,000 deaths (Ministério da Saúde, 2021a). During the month of March, in the work to contain the spread of the virus, several measures were implemented, including physical distancing, home withdrawal and the closure of public spaces, such as educational establishments. In their homes, and deprived of the traditional education model, with the closure of schools and universities, distance learning was the solution provided by many countries (Golberstein et al., 2020).

According to UNESCO (2020), more than 90\% of students worldwide have been affected by these measures, with impacts on physical, mental, emotional and academic levels (The Lancet Child Adolescent Health, 2020). Several studies have demonstrated the effects of lockdown on this specific group (e.g., Branquinho et al., 2020; Kecojevic et al., 2020; Singh et al., 2020; Matos \& Wainwright, 2021). With regard to mental health, a systematic literature review (Loades et al., 2020) revealed that the impact of loneliness will lead to an increased risk of depression and anxiety post-lockdown, a fact confirmed by Magson et al. (2021). In a study distinguishing the characteristics associated with greater stress during this period, young people and females were highlighted as experiencing greater stress (Kowal et al., 2020). A stress that can be explained by changes in routines, inability to maintain some coping strategies, and associated with the adoption of risk behaviours, such as higher food intake, poorer sleep quality (Abbas et al., 2020), longer screen time (Schmidt et al., 2020; Xiang et al., 2020), and fewer health behaviours, such as physical activity (Abbas et al., 2020; Schmidt et al., 2020; Xiang et al., 2020).

In September of the same year, at the beginning of the 2020/2021 school year, coinciding with the second wave of the pandemic, the Portuguese Government declares the situation under control and educational establishments reopen, complying with WHO (2021) regulations for the containment of the virus, such as the mandatory use of masks, physical distance in the classroom, prohibition of gatherings outside the classrooms, frequent sanitisation and ventilation of spaces. However, after four months of classroom teaching (January 2021 - third wave of the disease) or a mixed regime in the case of universities, the number of cases suddenly rises, as do hospital admissions, and a new general lockdown is declared, already with the prospect of mass vaccination.

According to the Directorate-General of Health, 22.8 million vaccines will be made available in Portugal, which will allow for the vaccination of the entire eligible population of the country. In a plan based on the definition of priority groups, according to scientific and ethical criteria (Ministério da Saúde, 2021b), children and AYA are part of a non-priority group (SNS24, 2021), so their vaccination is not yet planned.

The return to face-to-face and mixed (university) education is now effective (March/April 2021), and teachers and employees of educational establishments are now part of the priority groups for anti-COVID-19 vaccination (DGS, 2021).

Recognising young people's skills to identify their problems, alongside strategies (Lerner et al., 2009), and their ability to become agents of change (Branquinho et al., 2020a; Checkoway \& Gutiérrez, 2006). This document, which compiles four studies, aims to tell the story of the pandemic based on the opinions and feelings of young Portuguese, to present their experience related to the impacts of the three waves of the COVID-19 pandemic (experienced in the country) on their lives, and their views related to vaccination.

\section{Methods}

The present work includes four research studies included in the project "Dream Teens: The Voice of Young People in Direct Speech" (Branquinho \& Matos, 2019; Matos, 2015), which obtained the approval of the Ethics Committee of the Lisbon Academic Centre of Medicine. The participants' informed consent or authorization from their legal representative (under 18 years of age) was a mandatory criterion for proceeding with the completion of the data collection instrument. For possible clarifications, the contact details of the research team were provided. 


\section{Design and Participants}

All studies had an exclusively online methodology and were disseminated through the research team's contacts, institutions linked to youth work and by Jovem Cascais/ Cascais Municipality. The four multi-method studies had different samples, but all were conducted with AYA aged 16-24 years old.

Table 1 - Data Collection and Participants

\begin{tabular}{|c|c|c|}
\hline Study & $\begin{array}{l}\text { Data } \\
\text { collection } \\
\text { period }\end{array}$ & Participants \\
\hline $\begin{array}{l}\text { Study } 1 \text { - } 1^{\text {st }} \\
\text { lockdown } \\
\text { (Branquinho } \\
\text { et al., 2020) }\end{array}$ & $\begin{array}{l}\text { April } 14 \text { to } \\
\text { May } 18,2020\end{array}$ & $\begin{array}{l}617 \text { participants } \\
(M=19.1 \text { years, } S D=2.352) \\
69.5 \% \text { were female; } 38.7 \% \\
\text { university students, } 35.8 \% \\
\text { high school and } 25.5 \% \\
\text { primary education }\end{array}$ \\
\hline $\begin{array}{l}\text { Study } 2 \\
\text { - Back to } \\
\text { school } \\
\text { (Branquinho } \\
\text { et al., 2021) }\end{array}$ & $\begin{array}{l}\text { October } 15 \text { to } \\
\text { November } 8 \text {, } \\
2020\end{array}$ & $\begin{array}{l}304 \text { AYA (Lisbon district, } \\
\text { most affected area) } \\
(M=18.4 \text { years, } S D=2.12 \text { ) } \\
71.1 \% \text { were girls; } 50.5 \% \\
\text { high school students and } \\
49.5 \% \text { universitary }\end{array}$ \\
\hline $\begin{array}{l}\text { Study } 3-2^{\text {nd }} \\
\text { lockdown } \\
\text { (Branquinho } \\
\text { et al., 2021) }\end{array}$ & $\begin{array}{l}\text { February } 2 \\
\text { to March } 22 \text {, } \\
2021\end{array}$ & $\begin{array}{l}592 \text { respondents } \\
(M=19.01 \text { years, } S D=2.32) \\
70.9 \% \text { were female; } 55.1 \% \\
\text { high school and } 44.9 \% \\
\text { university students }\end{array}$ \\
\hline $\begin{array}{l}\text { Study } 4 \text { - } \\
\text { Vaccination } \\
\text { (Branquinho } \\
\text { et al., 2021b } \\
\text { submitted) }\end{array}$ & $\begin{array}{l}\text { December } \\
28,2020 \text { to } \\
\text { January } 24 \text {, } \\
2021\end{array}$ & $\begin{array}{l}558 \text { participants } \\
(M=19.34 \text { years, } S D= \\
2.266) \\
72 \% \text { were girls; } 60.8 \% \\
\text { university students and } \\
39.2 \% \text { high school }\end{array}$ \\
\hline
\end{tabular}

\section{Instruments}

All data collection instruments included sociodemographic questions, such as age, gender, nationality, educational level and questions about work (student, worker/student, other_what?) and had a response time variability between 7 and 20 minutes. The specific questions of each instrument included:

- Study $1-1^{\text {st }}$ lockdown (Branquinho et al., 2020) - eight open-ended questions focusing on the impacts of the lockdown of the first wave of the pandemic COVID-19 on social and friendships (How might COVID-19 impact on your social life and friendship?), routines and daily life (How are you living this social limitation in terms of the practical aspects of everyday life?), school, work, leisure (How do you cope with daily routines and work/study and leisure time balance?), health and well-being (What health problems may appear (e.g. sedentary behaviour, poor nutrition, poor sleep quality, substance abuse, feelings of boredom/anxiety/depression, gambling disorders, excessive use of screen time and consequent family conflicts; How does COVID-19 affect your well-being?; Is it different for men and women? Younger and older? More and less economically privileged?), coping strategies (What can help you cope with this situation (family connections, more time, less fatigue)?) and lessons for future pandemics or a new wave of the disease (What lessons can they draw for future pandemics?).

- Study 2 - Back to school (Branquinho et al., 2021) - Eleven open-ended questions based on the return to school, related to the new school reality (How is the return to school post-confinement going?), how it would be affecting academic performance (How is it affecting academic performance/success?), relationships (family (How is it affecting family relationships?), friendship (How is it affecting friendship relationships?) and love (How is it affecting love relationships?), leisure activities (How is it affecting leisure activities?), sleep (How is it affecting sleep?), physical activity (How is it affecting physical activity?) and food (How is it affecting dietary pattern?), as well as what they find most (What was most enjoyable?) and least pleasant (What was less enjoyable?).

- Study $3-2^{\text {nd }}$ lockdown (Branquinho et al., 2021a) - Sixteen closed-ended questions (response options: no impact, positive, negative, not applicable) focused on the impact of the second general lockdown on health and well-being (What impact has the second confinement had on your health and wellbeing? - physical, mental, social), relationships (What impact has the second confinement had on your 
relationships? - family, friendships, love), health and risk behaviors (What impact has the second confinement had on your health and risk behaviors?_leisure, sleep, physical activity, diet, substance use, and screen time), and academics (What is the impact of the second confinement at school level? - performance, stress, relationships with teachers and peers). Each category included a non-mandatory open question to describe the impacts (If you have identified impacts on your ..., we ask you to describe them), and at the end, two questions allowed to study what they felt was worse (What was really worse in these times of confinement...) and the coping strategies (Which has helped me a lot in these times of confinement....).

- Study 4 - Vaccination (Branquinho et al., 2021b submitted) - four closed-ended questions related to their expectations of anti-COVID-19 vaccination (What will change when we start getting vaccinated? (You can select more than 1 option) than 1 option) (a) Soon the transmission between people will decrease, and allow us to return to normality; (b) It will take time, only when $70 \%$ of the population is vaccinated will we be able to we can return to normality; (c) The wearing of masks and social distancing will continue to be part of our lives for a long time to come; (d) Even with the vaccine and the pandemic eradicated, our lives will never be the same again. the same; (e) Nothing will change, no vaccine is $100 \%$ effective; ( $f$ ) other), advantages and fears (People's advantages and fears about vaccinations... (You can select more than 1 option) - (a) The use of masks and social distancing will not be effective in combating the pandemic, only with vaccination will we be able to extinguish COVID-19; (b) Getting vaccinated can help prevent further complications, even if you get infected; (c) Getting vaccinated can help protect people, especially those most at risk; (d) I do not trust the safety and effectiveness of vaccines; (e) I am afraid of the adverse effects of vaccination; (f) other), whether the vaccines should be targeted to all or to specific groups (Should the vaccine be for all or only for specific groups? (Select only 1 option) (a) For all; (b) As planned by the Government:
3 phases excluding pregnant women and children; (c) For specific groups), and in case of response from specific groups, select which ones (older, younger, chronically ill, governments, health professionals, education professionals, police forces, supply staff, other).

\section{Data Analysis}

Data from the sociodemographic questions and other closed-ended questions were treated with the quantitative analysis software SPSS v. 26 , Chi-Square test. Studies 2, 3 were also analysed using a qualititative methodology, based on the coding below-mentioned, and study 4 adopted this methodology exclusively.

The analyses of the data collected through the open-ended questions were first analysed using the Bardain method - pre-analysis of the material, exploration, treatment of the results obtained and interpretation (2011), and then checked using the qualitative analysis software MAXQDA 2020. This qualitative data analysis software allowed importing the analysis data based on Bardain's method (2011), creating the identified categories (C) and subcategories (SC), and through codes and colours according to their similarity, coding them according to the perception of impacts (positive, negative, neutral). The use of MAXQDA 2020 was a facilitator in the visualisation of the data, through MaxMaps and word cloud, in the extraction of the coded segments (young people's texts) and analysis and intra-jury agreement (CB and MGM). The categories and subcategories created had an intra-jury agreement of $100 \%$.

Study 1 - $1^{\text {st }}$ lockdown (Branquinho et al., 2020): (C1) impacto na vida social e relações de amizade; (C2) impacto na vida diária e rotinas; (C3) impacto na saúde e bem-estar; (C4) estratégias de coping; (C5) lições para futuras pandemias.

Study 2 - Back to school (Branquinho et al., 2021): (C1) school - (SC1.1) the new school reality; (SC1.2) how previous confinement affected school performance; (C2) relationships - (SC2.1) family, (SC2.2) friendships and (SC2.3) loving relationships; (C3) health behaviours - (C3.1) leisure activities, (SC3.2) sleep patterns, (SC3.3) physical activity and 
(SB3.4) dietary pattern; alongside with what was more pleasant (C4) and less pleasant (C5), in their opinion.

Study 3 - In the third wave of the pandemic, coinciding with the $2^{\text {nd }}$ lockdown (Branquinho et al., 2021a): (C1) health and well-being; (C2) relationships; ( $\left.\mathrm{C}_{3}\right)$ health and risk behaviors; ( 4 4) academic; (C5) what they felt as most negative; (C6) coping strategies.

\section{Results}

In the results of this paper, an aggregative description of the quantitative and qualitative results gathered in each of the studies will be presented. In Study 1 - $1^{\text {st }}$ lockdown (Branquinho et al., 2020), the AYA identified impacts on the developmental domains at the social level, highlighting the loss of social contacts, decreased physical contact, lower confidence and decreased interpersonal skills, but also a greater strengthening of friendships and selection of existing ones. In the emotional field, an increase in depressive symptoms, anxiety and loneliness, an increase in family discussions and the loss of important moments in life were reported, although some positive points were highlighted, such as greater relaxation and less fatigue. Regarding behaviours, the absence of routine, lower productivity, more screen time and substance consumption were mentioned, but also a greater availability of time to practice pleasurable activities, such as physical exercise, and for personal and professional enrichment training - cognitive domain. At a physiological level, they reported changes in sleep and eating patterns, and muscle and headaches, with no positive points identified. Also at the educational level, only negative consequences were mentioned, such as the higher volume of homework; as well as in the structural domain, the decrease in the families' financial capacity was highlighted.

They believed that the regular contact with family and friends had helped them to cope with the pandemic, to have a routine and defined schedules, to perform enjoyable activities and personal and professional enrichment.

For future pandemics or a new wave of the disease, they highlighted better preparation on the part of the General Directorate of Health, as well as training on the part of teachers and students for online learning; and support in routines using television.

Study 2 - Back to school (Branquinho et al., 2021) after the first confinement showed that in general, AYAs perceived the new school reality in a more pessimistic way. A considerable percentage (43.8\%) of AYAs have a pessimistic view of the new post-confinement school reality, especially those who maintain blended education, defining it as strange, tiring and confusing and that teachers are not well prepared. Those who have returned to face-to-face teaching also experience it as more disorganised and challenging, even though they stress that face-to-face teaching is much better than online. Their negative outlook (57\%) remains on academic performance, pointing out that the mixed methodology lacks dynamism and reduces productivity and concentration. Although the AYAs who returned to face-to-face classes emphasised that using the mask was tiring, they said that faceto-face teaching had improved their performance.

With regard to relationships, most of them did not point out negative or positive impacts on family (50.3\%) and love relationships (62.3\%), but on friendships, they argued negative impacts (57.8\%), mentioning that the alternation of schedules caused a distancing from their friends and that school makes socialisation more difficult.

In health and well-being behaviours, most of them referred to neutral impacts on sleep (57.7\%) and eating (62.2\%), but in terms of leisure (70\%) and physical activities (53.1\%), they highlighted negative consequences, such as the offer of few safe activities, the lack of time and motivation, and the constraints in Physical Education classes.

The most pleasant aspects of the return to school were the socialisation and the teacherstudent interaction, the reencounter with friends and the face-to-face classes; and the least pleasant were the less physical contact, the rules and norms, the feelings of insecurity, the mixed method, the less socialisation and the use of public transport.

Overall, and based on the coding of impacts (positive, negative and neutral) and the respective 
quantitative data analysis, university students and girls were the least positive in describing the impacts of the pandemic on their return to school.

Study 3 - In the third wave of the pandemic, coinciding with the $2^{\text {nd }}$ lockdown (Branquinho et al., 2021a), young people were globally negative in their answers.

In the study of the impacts on health and risk behaviours, the neutral (40.5\%) or negative (35.6\%) impacts on health and well-being are widely emphasized, highlighting the greater psychological and physical symptoms, increased demotivation, stress and concentration difficulties; as well as on sleep, with emphasis on changes in sleep patterns.

In relationships, negative consequences are reinforced (55.9\%), such as increased family discussions and distancing from risk relatives, such as grandparents, loss of friendships and deterioration of love relationships.

In leisure activities, 44.9\% highlight neutral and $33.6 \%$ positive impacts, such as the greater availability for practice, inverting these results to negative (35.8\%) and neutral (34\%) in physical activity, which decreased partially or totally, and the prohibition of the practice of collective sports.

Neutral impacts are essentially attributed to sleep (53\%) and diet (45.4\%), but a deregulation of the sleep pattern is also highlighted. With regard to diet the opposite happens, with some people thinking that it is easier to have a better diet at home.

Regarding substance use, $48.8 \%$ reported not to apply, due to the absence of consumption, and in terms of screen time, $70.4 \%$ showed an insight, with the increase in screen time spent in leisure time and school activities. At the academic level, although neutral impacts were perceived on relationships with teachers and peers (51.9\%) as well as academic performance (38.9\%), they highlighted that academic stress had worsened $(46.5 \%)$. As worse, they commented on decreased socialisation and loss of freedom, inability to play sports, and impact on mental health.

As coping strategies, family support, contact with friends, sleep, indoor leisure activities, mainly on screen, and outdoor activities, such as running, were mentioned.
Again, and again based on the quantitative analysis of the description of impacts (positive, negative, neutral), university students and young women were less positive in their descriptions of the impacts of the second general confinement.

Study 4 - Vaccination (Branquinho et al., 2021b submitted), was a last study ithat intended to understand AYA attitudes towards vaccins. When asked about what would change with vaccination, $74.7 \%$ agreed that vaccination would take time to have an effect and that only when $70 \%$ of the population had been vaccinated could we return to normality; $72.4 \%$ that the use of masks and physical distance would be part of our lives for a long time; $29.6 \%$ that even with the vaccines and the pandemic eradicated, our lives would never be the same again; $10.6 \%$ that the transmission between people would quickly decrease and allow us to return to normality; and $3 \%$ that a vaccine would not change anything, because there was no $100 \%$ effectiveness.

When asked about fears and advantages, $81 \%$ believed that being vaccinated could help protect people, particularly the risk groups; $50.2 \%$ that being vaccinated could help prevent further complications, even if infected; $37.8 \%$ were afraid of the side effects of vaccination; $24.7 \%$ that wearing a mask and staying away would not be effective by itself and that vaccination was fundamental in combating the pandemic; and 9.1\% did not trust the safety and efficacy of vaccines. In their openended responses, they reported fears of the time taken to develop and test the vaccines.

Finally, when asked whether the vaccine should be for all or specific groups, 55.6\% concluded that it should be for all. Those who answered specific groups prioritised the elderly ( $9 \%$ ), healthcare professionals (8.1\%) and the chronically ill (7.5\%).

\section{Discussion and conclusions}

This compilation-paper presents the story of COVID-19 pandemic based on the opinions and feelings of young Portuguese, presenting their experience related to the impacts of the three waves of pandemic on their lives, and their views related to vaccination. 
Developed at four distinct moments of the COVID-19 pandemic, these studies show congruent results. If in the first general lockdown (Study 1 - $1^{\text {st }}$ lockdown; Branquinho et al., 2020), the AYAs identified numerous (and predominantly negative) impacts at the levels:

Social - alienation from friends and loss of friendships. Knowing that socialisation with peers is one of the main developmental components at this stage of life, this area was expected to be negatively affected (Brooks et al., 2020; Tomé et al., 2021);

Emotional - increased depressive symptoms, anxiety and feelings of loneliness. Other studies have shown that feelings of loneliness experienced during confinement could potentiate the risk of depression and loneliness in deconfinement (Loades et al., 2020; Magson et al., 2020);

Family - more discussions and conflicts. After a family organisation "imposed" by confinement, and stress caused by decreased social contacts (Fegert et al., 2020), the AYAs reported a greater closeness to the family;

Behavioural - lower productivity, motivation, longer screen time as also highlighted in other studies (Schmidt et al., 2020; Xiang et al., 2020), but longer time for physical activity;

Cognitive - greater availability for personal and professional enrichment;

Physiological - changes in sleep pattern, diet and physical pain. Another study focusing on the impacts of the pandemic and with this population, revealed higher food intake and poorer sleep quality during the pandemic (Abbas et al., 2020);

Academic - higher amount of homework;

Structural - decrease in the financial capacity of the family, which can be the result of job losses associated with the implications in the various economic sectors (Nicola et al., 2020).

Looking forward to the return to face-to-face teaching, the AYAs were confronted with a new reality (Study 2 - Back to school; Branquinho et al., 2021). With divergent teaching methodologies, as the secondary school adolescents returned to face-to-face teaching and the university students maintained a mixed methodology, the secondary school students considered face-to-face teaching to be disorganized and challenging, even though being with their friends overcame any difficulty; and the university students considered it strange and tiring, highlighting that the teachers were not prepared. Even though formative provision for online classroom delivery has existed (Schleicher, 2020), the most effective practices are still or will be explored (Petrie, 2020). They also mentioned that productivity, concentration and motivation were scarce in the mixed regime. While these results contradict Gonzalez et al.'s (2020) study that confinement altered learning strategies, increasing efficiency, they support Di Pietro and colleagues (2020) who argue that online learning causes less time spent learning, higher stress and lower motivation. Secondary school students, on the other hand, considered a return to face-toface to have improved academic performance.

At the level of relationships also in this work changes in relational patterns are highlighted (Di Pietro et al., 2020), even though face-to-face affected family time, university students stressed the increase in discussions due to feelings of irritation and anxiety; in friendships, face-to-face showed that school had ceased to be a space promoting socialization (Garbarino, 1978; Garibaldi \& Josias, 2015); and in love relationships the difficulty in reconciling schedules for high school youth, but a greater time freedom for university students.

Leisure was the area most commonly perceived as negatively affected, with AYAs stressing that it was difficult to find something safe, that they lacked motivation and that the classes did not allow for much free time. Physical activity was also reported as negatively affected, mainly due to the incompatibility of schedules and time availability. Sleep and feeding were also affected, with the inperson (secondary) confinement decreasing the number of hours of sleep and hindering healthy eating; and the mixed regime having switched sleep schedules and skipping meals. These areas had already been affected in both confinements, reinforcing other studies (Abbas et al., 2020). It is highlighted that these areas, as well as the academic area, in which young people show greater stress, are important predictors of well- 
being, so support for AYAs in restoring (or adopting) these health behaviours is urgently needed.

This study was in agreement with the study of Kowal et al. (2020), showing a more negative perspective on the part of females, who may experience more stress.

Similar results of study 1 were found in Study 3 $2^{\text {nd }}$ lockdown (Branquinho et al., 2021a), developed in a similar situation, except for the structural component which was not highlighted and the decrease in physical activity. Other studies also revealed a decrease in this health behaviour during lockdown (Abbas et al., 2020; Schmidt et al., 2020; Xiang et al., 2020).

With regard to vaccination, we found that most AYAs are well informed and aware of the general aspects of the pandemic, knowing that $70 \%$ of the population needs to be vaccinated to achieve group immunity and that the measures to contain the pandemic will last (DGS, 2021). As for fears and advantages, they believe in its protective role, mainly for risk groups and about half of the respondents believed that vaccination should be for everyone, not only for specific groups. The expected benefits of the vaccine are more influential than the perspective of its side effects (Kaplan \& Milstein, 2021).

In a pandemic fatigue, AYAs reported that regular communication with family and friends, physical exercise, personal and professional enrichment, and the establishment of routines and schedules helped them cope with the impacts of the pandemic. Other studies highlight the importance of establishing routines and schedules as a coping strategy during this scenario (Almeida et al., 2020; Deslandes \& Coutinho, 2020).

For future pandemics or a new wave of the disease, they highlighted a better preparation on the part of the General Direction of Health, as well as, training for teachers and students for online teaching; and support in routines using television, a resource facilitated to the entire population, regardless of age group.

\section{Strenghts and limitations}

Although these studies are (based on our knowledge and literature research) the first to give AYAs the opportunity to express their opinions and feelings related to impacts of each of the three pandemic waves on their lives and antiCOVID-19 vaccination, we found some limitations. The first relates to the vast majority of responses being female and from young people in university education. The second, and due to the virus containment measures, the collection of data exclusively online, making it impossible to deepen the answers. The third and last one is the difficulty in comparing these results with similar studies, since no similar studies were found.

\section{References}

Abbas, A. M., Fathy, S. K., Fawzy, A. T., Salem, A. S., \& Shawky, M. S. (2020). The mutual effects of COVID-19 and obesity. Obesity medicine, 19. Article 100250. https:// doi. org/10.1016/j.obmed.2020.100250

Almeida, R. S., Brito, A. R., Alves, A. S. M., de Abranches, C. D., Wanderley, D., Crenzel, G., Lima, R. C., \& Barros, V. F. R. (2020). Pandemia de COVID-19: guia prático para promoção da saúde mental de crianças e adolescentes IPandemic COVID-19: a practical guide to promote child and adolescent mental health]. Residência Pediátrica, 10(2), 1-4.

Bardin L. (2011). Content Analysis. Edições 70.

Branquinho, C., \& Matos, M. G. (2019). The "dream teens" project: After a two-year participatory action-research program. Child Indicators Research, 12(4), 1243-57. https://doi.org/10.1007/s12187-018-9585-9

Branquinho, C., Colette, K., Arevalo, L., Santos, A., \& Matos, M. G. (2020). "Hey, we also have something to say": A qualitative study of Portuguese adolescents' and young people's experiences under COVID-19. Journal of Community Psychology, 48(8), 2740-2752. https://doi.org/10.1002/jcop.22453

Branquinho, C., Machado, M. C., Noronha, C., \& Matos, M. G. (submitted, 2021). Vacinação COVID-19 e Participação Juvenil: Envolvimento dos jovens num assunto que afeta as suas vidas ICOVID-19 Vaccination and Youth Participation: Engaging young people in an issue that affects their Lives]. Análisis y Modificación de Conducta.

Branquinho, C., Santos, A., Noronha, C., Ramiro, L., \& Matos, M. G. (2021a). COVID-19 pandemic and the second lockdown: the 3rd wave of the disease through the voice of Youth. Child Indicators Research. https:// doi.org/10.1007/s12187-021-09865-6

Branquinho, C., Santos, A., Ramiro, L., \& Matos, M. G. (2021). COVID\#BACKTOSCHOOL: A mixed study based on the Voice of portuguese adolescentes. Journal of Community Psychology. https://doi.org/10.1002/jcop.22670 
Brooks, S.K., Webster, R.K., Smith, L.E., Woodland, L., Wessely, S., Greenburg, N., Rubin, G.J. (2020). The Psychological Impact of Quarantine and How to Reduce It: Rapid Review of the Evidence. The Lancet, 395, 912-920. https://www.thelancet.com/journals/lancet/article/ PIIS0140-6736(20)30460-8/fulltext

Checkoway, B. N., \& Gutiérrez, L. (2006). Youth Participation and Community Change: An Introduction. Journal of Community Practice, 14(1-2), 1-9. https://doi.org/10.1300/J125V14n01_01

Deslandes, S. F., \& Coutinho, T. (2020). O uso intensivo da internet por crianças e adolescentes no contexto da COVID-19 e os riscos para violências autoinflingidas [Intensive internet use by children and adolescents in the context of COVID-19 and the risks for self-inflicted violencel. Ciência \& Saúde Coletiva, 25, 2479-2486. https://www.scielo.br/j/csc/a/56TbmHfDsWJyK6DVJzjcHhp/?lang=pt

Di Pietro, G., Biagi, F., Costa, P., Karpiński, Z., \& Mazza, J. (2020). The Likely Impact of COVID-19 on Education: Reflections based on the Existing Literature and Recent International Datasets. In Publications Office of the European Union, Luxembourg: Vol. EUR 30275 (Issue JRC121071). https://doi.org/10.2760/126686

Direção-Geral da Saúde (DGS) (2021). COVID-19: ponto de situação atual em Portugal ICOVID-19: current situation in Portugall. https://covid19.min-saude.pt/ vacinacao

Garbarino, J. (1978). The Role of Schools in Socialization to Adulthood. The Educational Forum, 42(2), 169-181. https://doi.org/10.1080/00131727809336299

Garibaldi, M., \& Josias, L. (2015). Designing schools to support socialization processes of students. Procedia Manufacturing, 3, 1587-1594. https://doi.org/10.1016/j. promfg.2015.07.446

Golberstein, E., Wen, H., \& Miller, B.F. (2020) Coronavirus Disease 2019 (COVID-19) and Mental Health for Children and Adolescents. JAMA Pediatriatrics, 174(9), 819-820. https://doi.org/10.1001/jamapediatrics.2020.1456

Gonzalez, T., de la Rubia, M. A., Hincz, K. P., Comas-Lopez, M., Subirats, L., Fort, S., \& Sacha, G. M. (2020). Influence of COVID-19 confinement on students' performance in higher education. PloS one, 15(10), Article e0239490. https://doi.org/10.1371/journal.pone.0239490

Fegert, J. M., Vitiello, B., Plener, P. L., \& Clemens, V. (2020). Challenges and burden of the coronavirus 2019 (COVID-19) pandemic for child and adolescent mental health: A narrative review to highlight clinical and research needs in the acute phase and the long return to normality. Child and Adolescent Psychiatry and Mental Health, 14, 20. https://doi.org/10.1186/ s13034-020-00329-3

Kaplan, R. M., \& Milstein, A. (2021). Influence of a COVID-19 vaccine's effectiveness and safety profile on vaccination acceptance. Proceedings of the National Academy of Sciences of the United States of America, 118(10), Article e2021726118. https://doi.org/10.1073/ pnas. 2021726118
Kecojevic, A., Basch, C. H., Sullivan, M., \& Davi, N. K. (2020). The impact of the COVID-19 epidemic on mental health of undergraduate students in New Jersey, cross-sectional study. PloS one, 15(9), Article e0239696. https://doi.org/10.1371/journal.pone.0239696

Kowal, M., Coll-Martín, T., Ikizer, G., Rasmussen, J., Eichel, K., Studzińska, A., Koszałkowska, K., Karwowski, M., Najmussaqib, A., Pankowski, D., Lieberoth, A., \& Ahmed, O. (2020). Who is the most stressed during the COVID-19 pandemic? Data from 26 countries and areas. Applied Psychology: Health and Well-Being, 12(4), 946-966. https://doi.org/10.1111/aphw.12234

Lerner, J. V., Phelps, E., Forman, Y. E., Bowers, E. P. (2009). Positive Youth Development. In R. M. Lerner, \& L. Steinberg (Eds), Handbook of Adolescent Psychology. Wiley Online Library.

Loades, M. E., Chatburn, E., Higson-Sweeney, N., Reynolds, S., Shafran, R., Brigden, A., Linney, C., McManus, M., Borwick, C., \& Crawley, E. (2020). Rapid systematic review: the impact of social isolation and loneliness on the mental health of children and adolescents in the context of COVID-19. Journal of the American Academy of Child \& Adolescent Psychiatry, 59(11), 1218-1239. https:// doi.org/10.1016/j.jaac.2020.05.009

Magson, N. R., Freeman, J., Rapee, R. M., Richardson, C. E., Oar, E. L., \& Fardouly, J. (2021). Risk and Protective Factors for Prospective Changes in Adolescent Mental Health during the COVID-19 Pandemic. Journal of youth and adolescence, 50(1), 44-57. https://doi.org/10.1007/ s10964-020-01332-9

Matos, M. G., \& Wainwright, T. (2020). COVID-19 and Mental health in School-Aged Children and Young People: Thinking ahead while preparing the return to school and to life "as usual". The Psychologist: Practice \& Research Journal, 4(1). https://10.33525/pprj.v4i1.105

Nicola, M., Alsafi, Z., Sohrabi, C., Kerwan, A., Al-Jabir, A., losifidis, C., Agha, M., \& Agha, R. (2020). The socio-economic implications of the coronavirus pandemic (COVID-19): A review. International Journal of Surgery, 78, 185-193. https:// doi.org/10.1016/j.ijsu.2020.04.018

Petrie, C. (2020). Spotlight: Quality education for all during COVID-19 crisis (hundrED Research Report \#01). United Nations. https://hundred.org/en/collections/ quality-education-for-all-during-coronavirus

Matos, M. G. (2015). Adolescentes: navegação segura por águas desconhecidas [Adolescents: navigation through unknown waters]. Lisboa: Coisas de Ler.

Ministério da Saúde (2021a). Relatório de Situação [Situation Report]. Available at https://covid19.min-saude. pt/relatorio-de-situacao

Ministério da Saúde (2021b). Vacinação COVID-19 [Vaccination COVID-19]. https://covid19.min-saude.pt/ vacinacao

Schleicher, A. (2020). The impact of COVID-19 on education: Insights from education at a glance 2020. OECD Journal: Economic Studies, 1-31. https://www.oecd.org/ education/the-impact-of-covid-19-on-education-insights-education-at-a-glance-2020.pdf 
Schmidt, S.C.E., Anedda, B., Burchartz, A., Eichsteller, A., Kolb, S., Nigg, C., Niessner, C., Oriwol, D., Worth, A., \& Woll, A. (2020). Physical activity and screen time of children and adolescents before and during the COVID-19 lockdown in Germany: a natural experiment. Scientific Reports, 10. Article 21780. https://doi.org/10.1038/ s41598-020-78438-4

Singh, S., Roy, D., Sinha, K., Parveen, S., Sharma, G., \& Joshi, G. (2020). Impact of COVID-19 and lockdown on mental health of children and adolescents: A narrative review with recommendations. Psychiatry Research, 293(August), Article 113429. https://doi.org/10.1016/j. psychres.2020.113429

Sistema Nacional de Saúde 24 (2021). Vacina COVID-19 [COVID-19 Vaccination]. Available at https://Ww/w.sns24. gov.pt/tema/doencas-infecciosas/covid-19/vacina-covid-19

The Lancet Child Adolescent Health. (2020). Pandemic school closures: Risks and opportunities. The Lancet. Child \& Adolescent Health, 4(5), 341. https://doi. org/10.1016/S2352-4642(20)30105-X

Tomé, G., Branquinho, C., Cerqueira, A., \& Matos, M. G. (2021). COVID-19, social distance and 'adolescents' risk behaviours, wellbeing and life satisfaction: a proxy study drawn from HBSC study. Análisis y Modificación de Conducta, 47(175), 19-33. https://dx.doi.org/10.33776/ amc.v47i175.4912

UNESCO (2020). A Comissão Futuros da Educação da Unesco apela ao planejamento antecipado contra o aumento das desigualdades após a COVID-19 lUnesco's Futures of Education Commission calls for early planning against rising inequalities after COVID-19]. Paris: Unesco, 16 abr. 2020. Retrieved January 25, 2021. from https://pt.unesco.org/news/comissao-futurosda-educacao-da-unesco-apela- ao planejamentoantecipado-o-aumento-das

World Health Organization, United Nations Educational, Scientific and Cultural Organization and United Nations Children's Fund (2020). Considerations for school-related public health measures in the context of COVID-19. In World Health Organisation (14 September 2020). https://www.who.int/publications-detail/risk-

Xiang, M., Zhang, Z., \& Kuwahara, K. (2020). Impact of COVID-19 pandemic on children and adolescents' lifestyle behavior larger than expected. Progress in Cardiovascular Diseases, 20, 30096-30097. https://doi. org/10.1016/j.pcad.2020. 04.013

\section{Cátia Branquinho}

Doutora em Ciências da Educação pela Faculdade de Motricidade Humana da Universidade de Lisboa, em Oeiras, Portugal; mestre em Psicologia Clínica pela Universidade Lusiada de Lisboa, em Lisboa, Portugal; investigadora do Projeto Aventura Social/ Faculdade de Motricidade Humana da Universidade de Lisboa, em Oeiras, Portugal, e do Instituto de Saúde Ambiental, Faculdade de Medicina da Universidade de Lisboa, em Lisboa, Portugal.

\section{Margarida Gaspar de Matos}

Doutora em Motricidade Humana pela Faculdade de Motricidade Humana da Universidade de Lisboa, em Oeiras, Portugal; Master of Education pelo Instituto Superior de Psicologia Aplicada, em Lisboa, Portugal e Universidade de Bristol, em Bristol, Inglaterra; coordenadora do Projeto Aventura Social/ Faculdade de Motricidade Humana da Universidade de Lisboa, em Oeiras, Portugal, e do Grupo Supportive Environments do Instituto de Saúde Ambiental, Faculdade de Medicina da Universidade de Lisboa, em Lisboa, Portugal; Professora Catedrática da Faculdade de Motricidade Humana da Universidade de Lisboa, em Oeiras, Portugal.

\section{Mailing address}

Cátia Branquinho

Universidade de Lisboa

Faculdade de Motricidade Humana

Estrada da Costa, 1499-002

Cruz Quebrada, Portugal

Os textos deste artigo foram conferidos pela Poá Comunicação e submetidos para validação do(s) autor(es) antes da publicação. 